\title{
ABSORPTION OF RADIOACTIVE SODIUM FROM THE INTESTINAL TRACT OF MAN. I. EFFECT OF INTESTINAL MOTILITY.* II. EFFECT OF AN ORGANOMERCURIAL $\dagger$
}

\author{
By VICTOR W. GROISSER $\ddagger$ AND JOHN T. FARRAR with THE TECHNICAL ASSISTANCE \\ oF GLORIA C. FERRIS \\ (From the Medical Service of the Veterans Administration Hospital, and the Department of \\ Medicine, Cornell University Medical College, New York, N. Y.)
}

(Submitted for publication March 14, 1960 ; accepted July 15, 1960)

The factors that may influence the kinetics of sodium absorption from the normal and the diseased human small intestine are not well defined. The importance of two such factors, intestinal motility and parenteral administration of organomercurials, was separately investigated in the present study.

The significance of intestinal motility in man has recently been evaluated $(3,4)$. In normal subjects, administration of methantheline bromide (Banthine) significantly reduced the rate of sodium absorption from the intestinal lumen (3). The diminished transport of sodium was considered to be due to the concomitant reduction in intestinal motor activity. In patients with sprue in relapse, the rate at which sodium entered the circulating blood from the small bowel was also significantly reduced $(4,5)$. The altered intestinal motor activity observed in this condition, as well as the presence of an enzymatic defect, was thought to play an important role in the abnormal sodium absorption (4).

The effect of mercurials on sodium absorption has been studied in animals. A similarity between the transport mechanisms in the renal tubular and intestinal epithelial cells was suggested by the observation that, when mixed with the saline, and administered into the intestine, various mercurial compounds caused a decrease in the rate of intestinal absorption of the sodium (6) and chloride ions $(6,7)$.

As a baseline for the present experiments, designed to evaluate the effect of motility and or-

* A portion of this work has been published in abstract form (1).

$\dagger$ Read in part by title at the Fifty-first Annual Meeting, American Society for Clinical Investigation, Atlantic City, N. J., May 4, 1959 (2).

$\ddagger$ Present address : Seton Hall College of Medicine and Dentistry, Jersey City, N. J. ganomercurial administration on sodium absorption, studies were initially performed to determine the characteristics of normal sodium transport, including a measure of variations in normal rates of absorption. The term "absorption" as used in this paper refers to the unidirectional transfer of sodium from the intestinal lumen into the arterial blood.

\section{METHODS}

\section{Sodium absorption}

Forty-five tests of radiosodium absorption were performed on 25 convalescent male hospital patients. All subjects were in normal electrolyte balance and were free of cardiac, hepatic, renal, endocrine and intestinal diseases. Their ages ranged from 25 to 70 , with a mean of 43 years.

The observations were made in the morning after an overnight fast of at least 8 hours. The patient remained supine throughout the test. A Miller-Abbott tube was passed under fluoroscopic guidance and its tip positioned in the jejunum approximately 20 to $30 \mathrm{~cm}$ beyond the ligament of Treitz. The location of the tube was recorded roentgenographically at the beginning and end of each study. A Cournand needle was inserted into the brachial artery and secured in place. Control samples of blood were obtained. Sodium ${ }^{24}, 10$ to $15 \mu \mathrm{c}$ in $30 \mathrm{ml}$ of isotonic saline warmed to $37^{\circ} \mathrm{C}$, was introduced into the proximal jejunum at a constant rate during a 60 second period. Sodium ${ }^{22}, 7$ to $12 \mu \mathrm{c}$ in $2 \mathrm{ml}$ of isotonic saline, was injected intravenously over a 10 second period, the mid-point of the intravenous injection coinciding with the mid-point of the sodium ${ }^{2}$ administration. During the second minute, the Miller-Abbott tube was flushed with $15 \mathrm{ml}$ of nonradioactive, isotonic saline. The mid-point of the sodium ${ }^{24}$ and sodium ${ }^{22}$ injections was considered to be zero time, and $4 \mathrm{ml}$ of arterial blood was withdrawn at 1-minute intervals for the first 12 minutes, at 3-minute intervals until 30 minutes had elapsed, and then at 5 to 10 -minute intervals up to 1 hour.

To determine the degree of reproducibility of the absorption of sodium a second test was performed on 9 patients under identical conditions 1 hour after the control study. In 11 patients, control studies preceded repeat tests performed after intravenous injection of propanthe- 
line bromide (Probanthine). In each repeat test, administration of sodium ${ }^{24}$ and sampling of arterial blood were performed exactly as in the control study. However, in order to minimize the contribution of the radioactivity present from the initial test, a much larger dose of sodium $^{24}, 50$ to $90 \mu \mathrm{c}$, was administered in the same quantity of isotonic saline. The plasma background for purposes of the second test was determined by averaging the radioactivity in two arterial samples drawn immediately prior to the administration of the second dose of sodium ${ }^{24}$. The decrease in this background radioactivity during the first 12 minutes of the repeat test was calculated by extrapolation to be less than 1 to 2 per cent of the total plasma radioactivity at 12 minutes. Absorption was almost complete at 12 minutes in both studies and it is this 12 minute period which is evaluated in greatest detail. The spaces of distribution determined during the control study for each patient were used in calculation of sodium absorption in both the control and repeat tests.

The concentration of isotopic sodium was determined by counting $2 \mathrm{ml}$ of plasma in a conventional well-type scintillation counter. Each sample of plasma containing both sodium $^{22}$ and sodium ${ }^{24}$ was counted for a period at least long enough to register 10,000 counts. One week later, the sodium $^{24}\left(\mathrm{~T}_{\frac{1}{2}}=15\right.$ hours $)$ had decayed to negligible levels, and the plasma was again counted to determine the sodium ${ }^{22}\left(\mathrm{~T}_{1}=2.6\right.$ years $)$ concentration. Sodium $^{24}$ plasma levels on the day of the test were calculated by subtracting the sodium ${ }^{22}$ contribution. The dose of sodium $^{22}$ and sodium ${ }^{24}$ administered was determined by correcting for the total residual radioactivity in the syringes and in the Miller-Abbott tube. Absorption rates were calculated by the formula of Scholer and Code (8) using each patient's observed serial sodium ${ }^{24}$ plasma concentration values and sodium ${ }^{22}$ spaces of distribution.

Conventional statistical methods were used to determine the 80 percentile range and linear correlation coeffcients $(R)$. The probability ( $p)$ that a correlation coefficient was obtained by chance was evaluated by analyses of variance and the $t$ test (9).

\section{Intestinal motility}

The motor activity of the small intestine was studied by detection and recording of intraluminal pressure in 21 studies. Two different systems were employed to record these pressure fluctuations. In 11 experiments a pressure-sensitive radio-telemetering capsule was used (10). In 10 tests a small balloon was connected via one lumen of a Miller-Abbott tube to a strain gage manometer (Statham). The balloon was 2 inches long, had a capacity of approximately $45 \mathrm{cc}$, and during recording was filled with $5 \mathrm{cc}$ of air. Intraluminal pressure was displayed oscilloscopically and permanently recorded by an oscillograph. In all studies, the pressure-detecting device was placed 1 to 1.5 feet distal to the point of administration of sodium $^{24}$ into the jejunum. When the radio-telemetering capsule was used, it was held stationary by a thin, peroral thread. When the small balloon was employed, the other lumen of the Miller-Abbott tube was used to administer the sodium ${ }^{24}$-saline solution. The intraluminal pressure records were analyzed for the presence of type I or "segmenting" waves and type III waves (11). For this investigation, type I waves are defined as simple, monophasic pressure waves of 2.5 to 7 seconds in duration. Type III waves are complex waves of longer duration, consisting of type I waves superimposed on an elevation of the baseline of at least $5 \mathrm{~cm}$ of $\mathrm{H}_{2} \mathrm{O}$. Determination was made of the percentage of time that type I and type III activity was present by measuring and summating the duration of each wave form. In addition, the average amplitude of the type I waves was calculated. Jejunal intraluminal pressure was recorded during 15 absorption experiments from the unstimulated small bowel of 11 patients. In 4 of the patients, pressures were recorded during a control and repeat absorption experiment performed under identical conditions. Following the control tests in 6 of the remaining patients, a repeat motility and absorption study was preceded by the intravenous administration of $0.3 \mathrm{mg}$ per $\mathrm{kg}$ of propantheline. In these studies, the second sodium ${ }^{24}$ absorption-motility test was timed to coincide with the occurrence of a definite anticholinergic effect, i.e., dry mouth, tachycardia or blurring vision.

In 6 additional patients who received propantheline, absorption of sodium $^{24}$ was determined after spreading the test saline solution over 2.5 to 3 feet of jejunal mucosal surface. Prior to the administration of propantheline, the tip of the Miller-Abbott tube was advanced to a point 4 to 5 feet distal to the ligament of Treitz. When a peripheral effect of propantheline was observed, mucosal spread of the saline was accomplished by steadily withdrawing a measured length of tubing (2.5 to 3 feet) during the period ( 1 minute) of continuous sodium ${ }^{24}$ administration.

$X$-ray studies. Preliminary to the radiosodium absorption experiments, radiographic studies were performed to gain information regarding: 1) the best location for placement of the Miller-Abbott tube, and 2) the rapidity of passage through the small bowel of a radiopaque solution administered at the same rate and in the same quantity as the sodium ${ }^{24}$ test solution and the subsequent flushing isotonic saline solution. Seventeen tests on 13 patients were performed. Thirty $\mathrm{ml}$ of sodium 3-acetylamino-2, 4, 6-triiodobenzoate (Urokon Sodium) was administered steadily into the small bowel through a MillerAbbott tube for 1 minute, followed by a wash of the same dye $(15 \mathrm{ml})$ during the second minute. Radiographs of the abdomen were taken at 1 minute after the midpoint of the initial injection, and then at 2, 5, 10 and 20 minutes.

In the first 6 tests, the tip of the Miller-Abbott tube was placed in the transverse duodenum. In 2 studies a small quantity of dye was noted to reflux into the stomach. Thereafter, to avoid reflux, the tip of the Miller-Abbott tube was placed approximately 20 to $30 \mathrm{~cm}$ distal to the ligament of Treitz for the additional $8 \mathrm{X}$-ray studies and for all of the subsequent sodium experiments.

Examination of the radiographs revealed that at 1 minute the dye was distributed over an area of approximately 1 to 1.5 feet of the jejunum, and at 5 minutes 
was dispersed throughout the jejunum and most of the ileum. At 10 minutes some of the dye had entered the proximal colon in several patients. In 3 additional patients, in whom X-ray studies were performed following propantheline administration, the radiopaque dye remained localized in the upper jejunum for a period of at least 20 minutes. Radiopaque marker substances were not used in the sodium ${ }^{24}$ absorption experiments, in order to avoid possible alterations in osmolarity and viscosity of the test saline solution.

\section{Mercaptomerin administration}

Eleven additional convalescent hospital patients were used in this study. Two tests of sodium $^{24}$ transport from intestinal lumen to arterial blood were performed on each patient. Since only intra-individual differences between arterial appearance curves of sodium $^{24}$ were analyzed, sodium $^{22}$ was not used and spaces of distribution were not determined. Sodium ${ }^{24}$ was administered as in the first portion of the study and arterial blood serially sampled. In addition, a multi-holed urinary catheter was inserted into the bladder of each patient and timed urine collections were made. At the end of each collection period, 100 to $200 \mathrm{cc}$ of air was injected to insure adequate collection. After the initial sodium ${ }^{24}$ absorption study and after at least two 15-minute urine collections, $2 \mathrm{ml}$ of mercaptomerin was given intravenously to each of the 11 patients. A second intestinal absorption test was performed 70 to 120 minutes after the first test and timed to coincide with a marked diuresis, if diuresis occurred.
Urinary sodium and chloride were determined by standard methods $(12,13)$.

Since no correction was made in these studies for variations in the "sodium space," experiments were carried out in 4 other patients to demonstrate that mercaptomerin did not appreciably alter the arterial disappearance curve of intravenously administered sodium. Sodium ${ }^{24}$ was given intravenously prior to mercaptomerin and an arterial disappearance curve plotted. The study was repeated after mercaptomerin and was timed to coincide with a urinary diuresis as in the absorption studies.

\section{RESULTS}

\section{Characteristics of sodium absorption in normal patients}

Rate and total quantity of sodium ${ }^{24}$ absorbed following intrajejunal administration in 22 patients. At 5 minutes a mean total of $61.7 \pm 15.3$ per cent, and at 12 minutes a mean total of $94.0 \pm$ 11.8 per cent of the administered dose were transferred from intestinal lumen to arterial blood (Figure 1a). Mean absorption during the eleventh minute was 3.9 per cent and during the twelfth minute, 1.8 per cent of the administered dose. By continuing the calculations to 21 minutes in 9 tests, increasingly small increments in the curve of
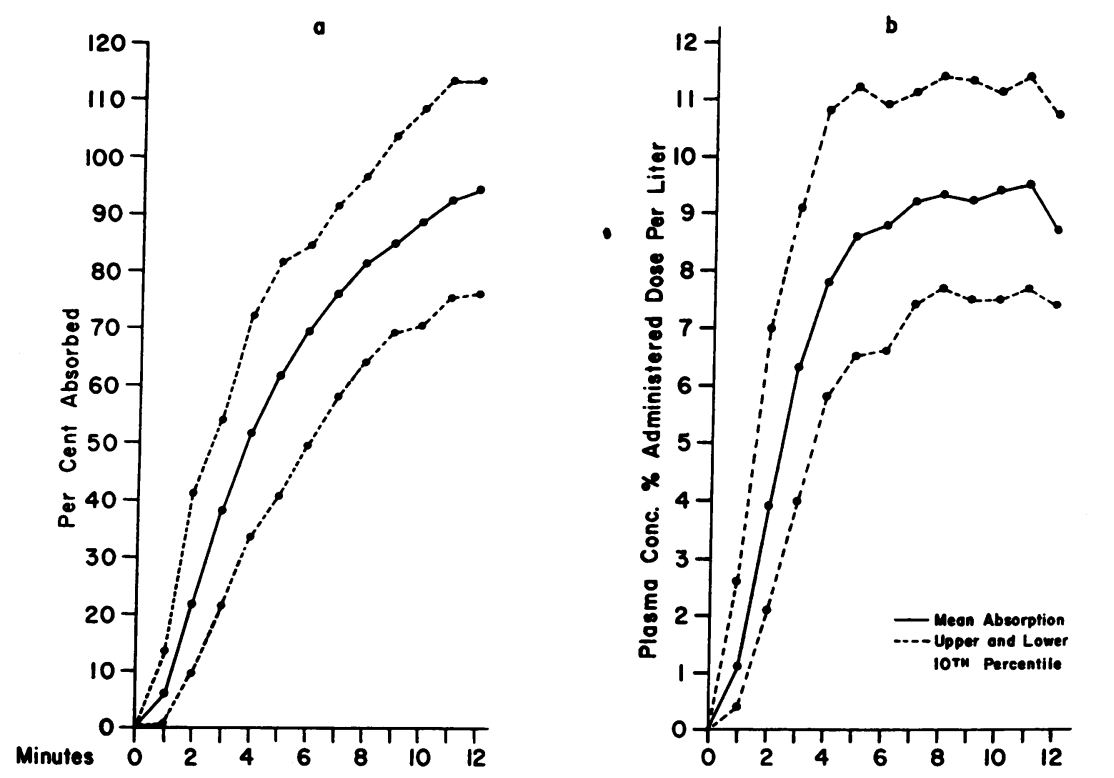

Fig. 1. a. QuANTITy of SODIUM ${ }^{24}$ ABSORBED From the SMALl INTESTINE of 22 NORMAL PATIENTS FOLLOWING INTRAJEJUNAL ADMINISTRATION, REPRESENTED AS PER CENT OF ADMINISTERED DOSE. b. RATE OF APPEARANCE OF SODIUM ${ }^{24}$ IN THE ARTERIAL BLOOD. The plasma concentration of sodium ${ }^{24}$ is represented as per cent of administered dose per liter. 


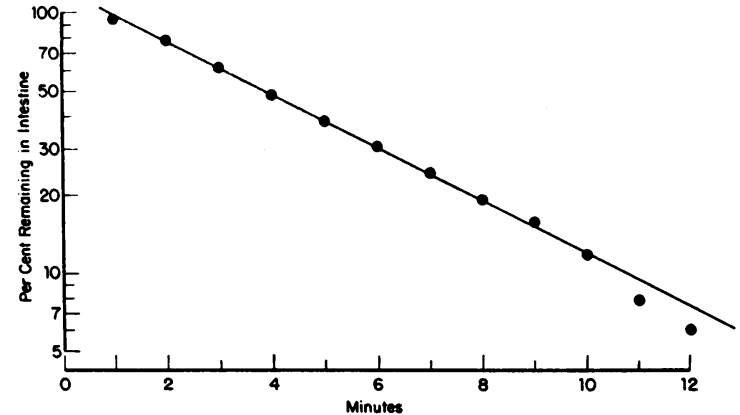

Fig. 2. Quantity of SOdiUm ${ }^{24}$ Remaining in the INTESTINE FOLLOWING INTRAJEJUNAL ADMINISTRATION. The rate of absorption is exponential between the second and tenth minute, during which approximately 90 per cent of the total dose is absorbed.

sodium $^{24}$ were noted, approaching or reaching zero absorption. In seven patients absorption of more than 100 per cent of the administered dose occurred at 12 minutes.

The mean rate of absorption of sodium ${ }^{24}$ in terms of the quantity in the intestinal lumen was exponential between the second and tenth minute - (Figure 2). During this period, 21 per cent of the amount remaining in the intestine was absorbed per minute.

The initial period during which the plasma concentration curve rose sharply (Figure 1b) cor- responded to the period during which the absorption curve also rose rapidly and the largest quantity of sodium ${ }^{24}$ was absorbed (Figure 1a). This might be expected, since the values for absorption of sodium ${ }^{24}$ were derived by integration of the arterial appearance of sodium ${ }^{24}$ and the disappearance of sodium ${ }^{22}$. The concentration value at 5 minutes was closely correlated $(\mathrm{R}=+0.91)$ with the average quantity absorbed per minute in the first 5 minutes. During this time more sodium ${ }^{24}$ entered the blood stream than left the intravascular space. At 8 minutes most of the sodium had been absorbed. By 12 minutes the concentration curve of sodium ${ }^{24}$ had already started to decline, while the cumulative absorption curve continued to rise. Thus, little correlation $(\mathrm{R}=+0.20)$ existed between the concentration value and the total quantity absorbed at 12 minutes.

There was close correlation $(\mathrm{R}=+0.96)$ between the average quantity absorbed per minute during the first 5 minutes and the time required for the absorption of 50 per cent of the administered dose. This suggests that in normal patients these measures may provide essentially the same information.

Evaluation of a repeat test of sodium absorption under identical conditions in 9 patients. Inspection of mean absorption and concentration curves
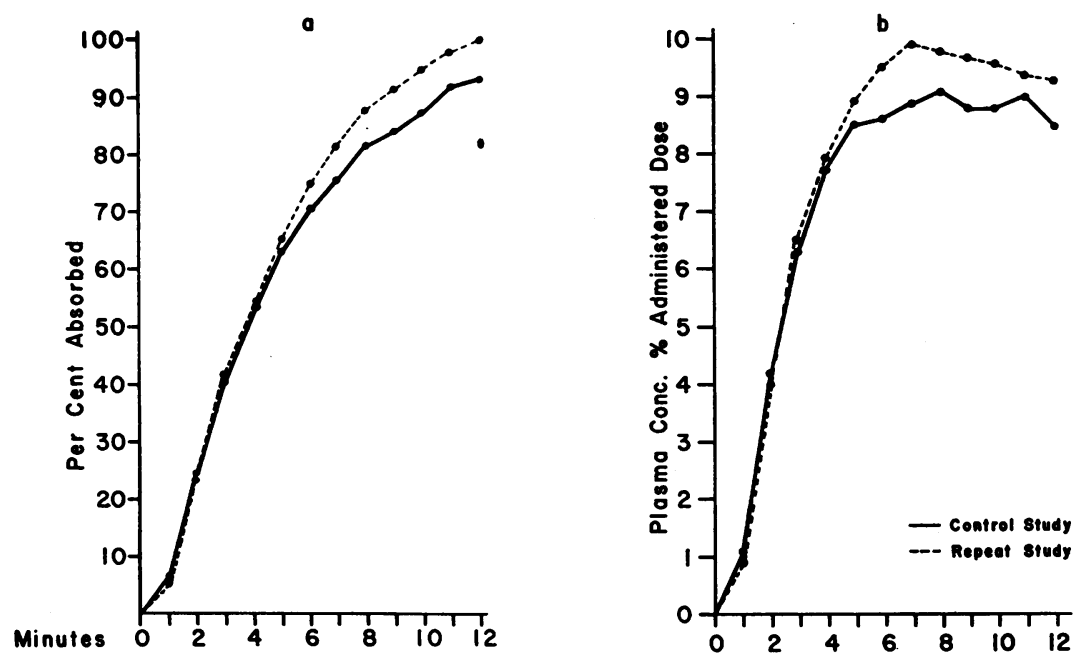

Fig. 3. a. MEAN ABSORPtion CURve (PER CENT AdMINISTEREd DOSE) OF SODIUM ${ }^{24}$ IN CONTROL AND REPEAT CONTROL STUDIES IN NINE NORMAL PATIENTS FOLLOWING INTRAJEJUNAL ADMINISTRATION OF SODIUM ${ }^{24}$. b. MEAN ARTERIAL CONCENTRATION OF SODIUM ${ }^{24}$ (PER CENT ADMINISTERED DOSE PER LITER) IN CONTROL AND REPEAT CONTROL STUDIES IN NINE NORMAL PATIENTS FOLLOWING INTRAJEJUNAL ADMINISTRATION OF SODIUM ${ }^{24}$. 
TABLE I

Variance analysis between control and repeat sodium absorption tests in 9 patients and single tests in 22 normal patients

\begin{tabular}{lccc}
\hline & $\begin{array}{c}\text { Concentration } \\
\text { at } \\
5 \mathrm{~min}\end{array}$ & $\begin{array}{c}\text { Absorption, } \\
50 \% \\
\text { of dose }\end{array}$ & $\begin{array}{c}\text { Absorption } \\
\text { rate, first } \\
5 \mathrm{~min}\end{array}$ \\
\hline $\begin{array}{c}\text { Variance between single } \\
\text { tests in 22 normal patients } \\
\text { Variance between single } \\
\text { tests in 9 normal patients } \\
\text { Variance between repeat tests } \\
\text { in each of the 9 normal patients }\end{array}$ & 3.32 & 1.56 & 9.34 \\
\hline \hline
\end{tabular}

(Figures $3 \mathrm{a}$ and $3 \mathrm{~b}$ ) for the control and repeat control test in 9 patients demonstrates the close reproducibility of sodium absorption studies in each patient. No significant differences were found between the two control tests for the following parameters: concentration values at $2,3,5$ and 8 minutes; and rates of absorption during the first 5 minutes and the 50 per cent absorption time. The total quantity absorbed at 12 minutes was greater in the repeat studies, the difference being statistically significant at the 5 per cent level. This difference at 12 minutes occurred at a time when little sodium was still being absorbed, and large technical errors can be expected. A significantly greater difference was found between single control tests on different patients than between two control tests on the same patient $(p<$ $0.05)$. A variance analysis (Table I) demonstrates the gain in the precision of the experiment when a patient is used as his own control.

\section{Relationship between intestinal motor function and absorption of sodium ${ }^{24}$ from the small bowel}

Correlation of absorption and motility from the normal small bowel in 11 patients. In the 11 patients in whom sodium ${ }^{24}$ transport and intraluminal pressure studies were measured simultaneously, absorption occurred at a rate similar to that noted for the larger group of 22 patients. A mean of 53 per cent of the administered sodium ${ }^{24}$ was absorbed in 5 minutes and a mean of 89 per cent was absorbed in 12 minutes. Intraluminal pressure recorded during 15 small intestinal absorption experiments varied widely from patient to patient (Table II). There was more intestinal motor activity in the first 5 minutes after administration of the test solution than in the succeeding 7 min- utes, possibly due to the motor response of the bowel to the presence of the sodium ${ }^{24}$-saline solution. The average time during which type I waves were present was 29 per cent of the total 12 minutes (range 2 to 82 per cent). The average amplitude of the type I waves varied for each patient from 0.5 to $14 \mathrm{~cm} \mathrm{H}_{2} \mathrm{O}$; mean for the group, $5 \mathrm{~cm}$ $\mathrm{H}_{2} \mathrm{O}$. Maximal amplitudes for type I waves for each patient ranged between 2 and $47 \mathrm{~cm} \mathrm{H}_{2} \mathrm{O}$. The average duration of type III activity during the 12 minute recording ranged from 0 to 16 per cent ; mean, 6 per cent.

Analysis of the data in 15 motility and absorption studies revealed that a positive though not striking correlation existed between percentage of time that type I waves were occurring and the quantities absorbed at 5 minutes $(\mathrm{R}=+0.63)$ and at 12 minutes $(R=+0.55)$, as determined by a comparison of the relative ranking of the motility and absorption values in this series. These correlations are significant at the 2 per cent and 5 per cent levels, respectively. There was no correlation $(R=+0.25$ or less) between either the amplitude of type I waves or the per cent duration of type III waves with the quantity of sodium that was transported from the intestinal lumen into the arterial circulation.

In the three (of four) patients in whom two control tests per subject were performed, an increase or decrease of the amount of type I activity in the repeat control test was always accompanied by a change in absorption in the same direction, although no correlation existed with the degree of change. The remaining patient J.O. (Table II) absorbed the same quantity of sodium at $12 \mathrm{~min}$ utes in both control tests, despite a considerable difference in motor activity.

Despite the finding of a moderate positive cor- 
relation between absorption and the occurrence of type I activity in the control studies, normal absorption was found to be associated with minimal motor function of any type in several patients (J.O., J.L., W.R., Table II).

Correlation of absorption and motility before and after propantheline administration. Administration of propantheline in eight patients significantly reduced sodium ${ }^{24}$. plasma absorption and concentration values (Figures $4 \mathrm{a}$ and $4 \mathrm{~b}$ ) as compared with control levels $(\mathrm{p}<0.05)$.

As an indication of a significant change from control levels, the initial slope of the post-anticholinergic plasma concentration curves (Figure 4b) afforded almost as much information as the calculated absorption data (Figure 4a). The degree to which absorption was diminished in individual patients varied considerably and did not correlate well $(\mathrm{R}=+0.28)$ with the control absorption values. (Figure 5). Nor was any correlation observed in these patients between the effect of propantheline on absorption and the severity of the anticholinergic effects such as tachycardia, xerostomia or blurred vision.

Intraluminal pressure was simultaneously recorded during the sodium absorption experiments in six of the eight patients before and after propantheline. Type I waves were abolished or markedly reduced following propantheline administration in four of the six patients. In the

TABLE II

Sodium ${ }^{24}$ absorption and intestinal motility

\begin{tabular}{|c|c|c|c|c|c|c|c|c|c|}
\hline & & \multirow{3}{*}{$\begin{array}{l}\text { Quantity } \\
\text { absorbed } \\
\text { at } 5 \mathrm{~min}\end{array}$} & \multicolumn{3}{|c|}{$\begin{array}{l}\text { Pressure waves during first } \\
5 \text { minutes }\end{array}$} & \multirow{3}{*}{$\begin{array}{l}\text { Quantity } \\
\text { absorbed } \\
\text { at } 12 \mathrm{~min}\end{array}$} & \multicolumn{3}{|c|}{$\begin{array}{l}\text { Pressure waves during first } \\
12 \text { minutes }\end{array}$} \\
\hline \multirow{2}{*}{\multicolumn{2}{|c|}{ Patient }} & & \multicolumn{2}{|c|}{ Type I } & \multirow{2}{*}{$\begin{array}{c}\text { Type III } \\
\text { Time } \\
\text { present }\end{array}$} & & \multicolumn{2}{|c|}{ Type I } & \multirow{2}{*}{$\begin{array}{c}\text { Type III } \\
\text { Time } \\
\text { present }\end{array}$} \\
\hline & & & $\begin{array}{l}\text { Time } \\
\text { present }\end{array}$ & Av. amp. & & & $\begin{array}{c}\text { Time } \\
\text { present }\end{array}$ & Av. amp. & \\
\hline & & $\%$ of dose & $\%$ & $c \mathrm{c} \mathrm{H}_{2} \mathrm{O}$ & $\%$ & $\%$ of dose & $\%$ & $\mathrm{Cc} \mathrm{H}_{2} \mathrm{O}$ & $\%$ \\
\hline \multicolumn{10}{|c|}{ I. Two control tests ( $a$ and $b$ ) } \\
\hline N.V. & $\begin{array}{l}\mathrm{a} \\
\mathrm{b}^{*}\end{array}$ & $\begin{array}{l}68.0 \\
75.5\end{array}$ & 14.1 & 9.9 & 3.3 & $\begin{array}{r}98.5 \\
114.2\end{array}$ & 28.2 & 11.7 & 3.8 \\
\hline H.H. & $\begin{array}{l}\mathrm{a} \\
\mathrm{b}\end{array}$ & $\begin{array}{l}58.0 \\
69.0\end{array}$ & $\begin{array}{l}38.1 \\
59.8\end{array}$ & $\begin{array}{l}5.7 \\
7.7\end{array}$ & $\begin{array}{r}3.3 \\
18.6\end{array}$ & $\begin{array}{l}88.4 \\
99.3\end{array}$ & $\begin{array}{l}31.9 \\
46.3\end{array}$ & $\begin{array}{l}4.4 \\
6.2\end{array}$ & $\begin{array}{r}1.3 \\
12.0\end{array}$ \\
\hline S.H. & $\begin{array}{l}\mathrm{a} \\
\mathrm{b}\end{array}$ & $\begin{array}{l}55.0 \\
66.5\end{array}$ & $\begin{array}{l}20.4 \\
36.8\end{array}$ & $\begin{array}{r}10.4 \\
6.7\end{array}$ & $\begin{array}{l}15.3 \\
14.3\end{array}$ & $\begin{array}{l}86.5 \\
85.6\end{array}$ & $\begin{array}{r}8.5 \\
25.9\end{array}$ & $\begin{array}{l}4.3 \\
5.2\end{array}$ & $\begin{array}{l}6.3 \\
5.9\end{array}$ \\
\hline J.O. & $\begin{array}{l}\mathrm{a} \\
\mathrm{b}\end{array}$ & $\begin{array}{l}51.0 \\
36.0\end{array}$ & $\begin{array}{r}40.0 \\
1.3\end{array}$ & $\begin{array}{r}16.0 \\
2.4\end{array}$ & $\begin{array}{r}16.0 \\
0.0\end{array}$ & $\begin{array}{l}92.3 \\
93.6\end{array}$ & $\begin{array}{r}28.1 \\
3.2\end{array}$ & $\begin{array}{r}13.7 \\
2.5\end{array}$ & $\begin{array}{r}16.1 \\
1.5\end{array}$ \\
\hline H.B. & $\begin{array}{l}\mathbf{a} \\
\mathbf{b}\end{array}$ & $\begin{array}{l}50.0 \\
60.0\end{array}$ & $\begin{array}{r}8.8 \\
34.5\end{array}$ & $\begin{array}{r}3.9 \\
33.8\end{array}$ & $\begin{array}{r}23.0 \\
2.3\end{array}$ & $\begin{array}{l}75.6 \\
90.2\end{array}$ & $\begin{array}{r}5.1 \\
40.3\end{array}$ & $\begin{array}{l}3.2 \\
3.7\end{array}$ & $\begin{array}{l}9.5 \\
1.0\end{array}$ \\
\hline \multicolumn{10}{|c|}{ II. Control (a) and propantheline (b) tests } \\
\hline G.P. & $\begin{array}{l}\mathrm{a} \\
\mathrm{b}\end{array}$ & $\begin{array}{l}37.0 \\
27.5\end{array}$ & $\begin{array}{r}23.8 \\
0.0\end{array}$ & $\begin{array}{l}9.3 \\
0.0\end{array}$ & $\begin{array}{r}23.0 \\
0.0\end{array}$ & $\begin{array}{l}68.8 \\
58.3\end{array}$ & $\begin{array}{r}31.2 \\
0.0\end{array}$ & $\begin{array}{l}6.8 \\
0.0\end{array}$ & $\begin{array}{r}11.9 \\
0.0\end{array}$ \\
\hline A.C. & $\begin{array}{l}\mathrm{a} \\
\mathrm{b}\end{array}$ & $\begin{array}{l}67.0 \\
40.0\end{array}$ & $\begin{array}{l}24.2 \\
48.5\end{array}$ & $\begin{array}{l}11.7 \\
13.4\end{array}$ & $\begin{array}{l}8.3 \\
0.0\end{array}$ & $\begin{array}{l}92.9 \\
74.3\end{array}$ & $\begin{array}{l}26.3 \\
59.3\end{array}$ & $\begin{array}{r}9.9 \\
20.9\end{array}$ & $\begin{array}{l}3.4 \\
3.6\end{array}$ \\
\hline J.S. & $\underset{b}{a \dagger}$ & $\begin{array}{r}46.5 \\
9.0\end{array}$ & & & & $\begin{array}{l}90.4 \\
27.6\end{array}$ & $\begin{array}{r}81.9 \\
2.5\end{array}$ & $\begin{array}{l}5.8 \\
0.5\end{array}$ & $\begin{array}{r}16.4 \\
0.0\end{array}$ \\
\hline L.G. & $\begin{array}{l}\mathrm{a} \\
\mathrm{b}\end{array}$ & $\begin{array}{l}67.0 \\
21.5\end{array}$ & $\begin{array}{l}64.6 \\
34.7\end{array}$ & $\begin{array}{l}1.6 \\
9.6\end{array}$ & $\begin{array}{l}0.0 \\
0.0\end{array}$ & $\begin{array}{r}102.7 \\
62.8\end{array}$ & $\begin{array}{l}64.1 \\
38.0\end{array}$ & $\begin{array}{l}1.4 \\
4.9\end{array}$ & $\begin{array}{l}0.0 \\
0.0\end{array}$ \\
\hline J.L. & $\begin{array}{l}\mathrm{a} \\
\mathrm{b}\end{array}$ & $\begin{array}{l}45.5 \\
25.5\end{array}$ & $\begin{array}{r}4.8 \\
61.8\end{array}$ & $\begin{array}{l}0.9 \\
9.2\end{array}$ & $\begin{array}{l}0.0 \\
0.0\end{array}$ & $\begin{array}{l}81.1 \\
48.8\end{array}$ & $\begin{array}{r}2.0 \\
46.5\end{array}$ & $\begin{array}{l}0.4 \\
8.0\end{array}$ & $\begin{array}{l}0.0 \\
0.0\end{array}$ \\
\hline W.R. & $\begin{array}{l}\mathrm{a} \\
\mathrm{b}\end{array}$ & $\begin{array}{l}47.0 \\
26.0\end{array}$ & $\begin{array}{l}0.0 \\
0.0\end{array}$ & $\begin{array}{l}1.1 \\
0.0\end{array}$ & $\begin{array}{l}0.0 \\
0.0\end{array}$ & $\begin{array}{l}81.1 \\
53.9\end{array}$ & $\begin{array}{l}0.0 \\
0.1\end{array}$ & $\begin{array}{l}1.1 \\
2.0\end{array}$ & $\begin{array}{l}0.0 \\
0.0\end{array}$ \\
\hline
\end{tabular}

* Repeat motility study not perormed.

$\dagger$ Twelve-minute motility record technically suitable for only 7 minutes. 

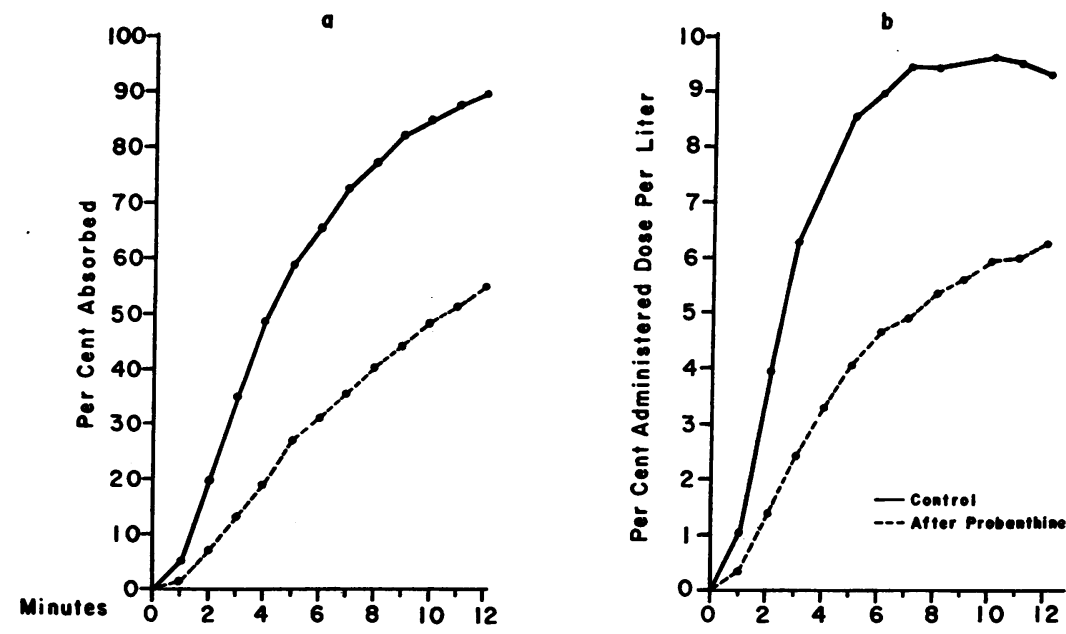

Fig. 4. a. MEAN ABSORPTION CURVES OF SODIUM ${ }^{24}$ IN EIGHT NORMAL PATIENTS before and after Probanthine administration. b. Mean arterial concenTRATION OF SODIUM ${ }^{24}$ IN EIGHT NORMAL PATIENTS BEFore AND AfTER PROBANTHINE ADMINISTRATION.

two remaining patients the total type I motor activity of the jejunum was significantly, although transiently, accentuated by the drug. Serial rhythmic, 11 minute, type I waves were noted for short periods before complete inhibition occurred. Effect of propantheline on type III activity could not be evaluated in three of the patients, since it was absent before the drug as well as after. Pro- pantheline did abolish type III waves, however, in the studies on two patients in whom they were present in the control study.

There was a reduction of both absorption and motor activity following propantheline administration in four patients, but no obvious correlation was noted between the degree to which each of these functions was depressed. In the two pa-

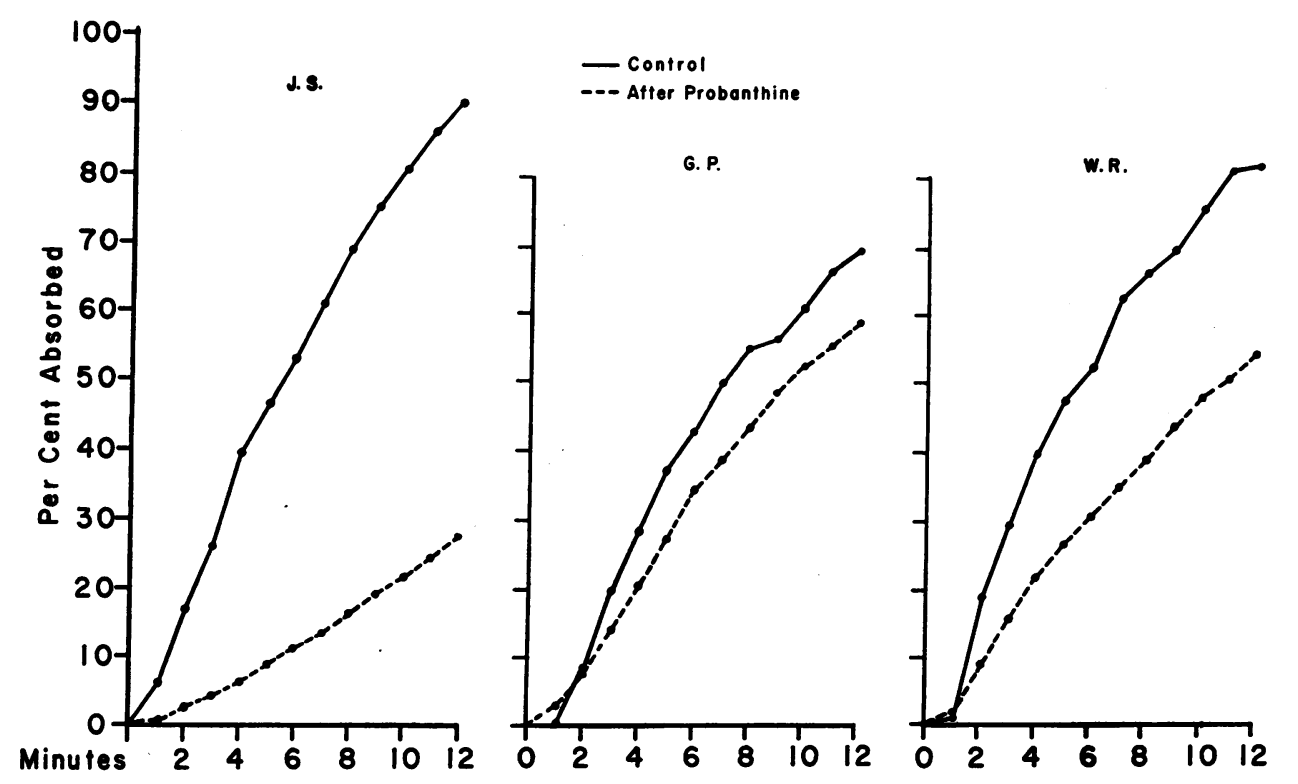

Fig. 5. Absorption of sodium ${ }^{24}$ in three normal patients before and after Probanthine ADMINISTRATION. There is no relationship between control levels of sodium ${ }^{24}$ absorption and the degree to which Probanthine depresses absorption. 
TABLE III

Renal effect of mercaptomerin* on urinary flow, and sodium and chloride excretion at beginning of repeat sodium ${ }^{24}$ study

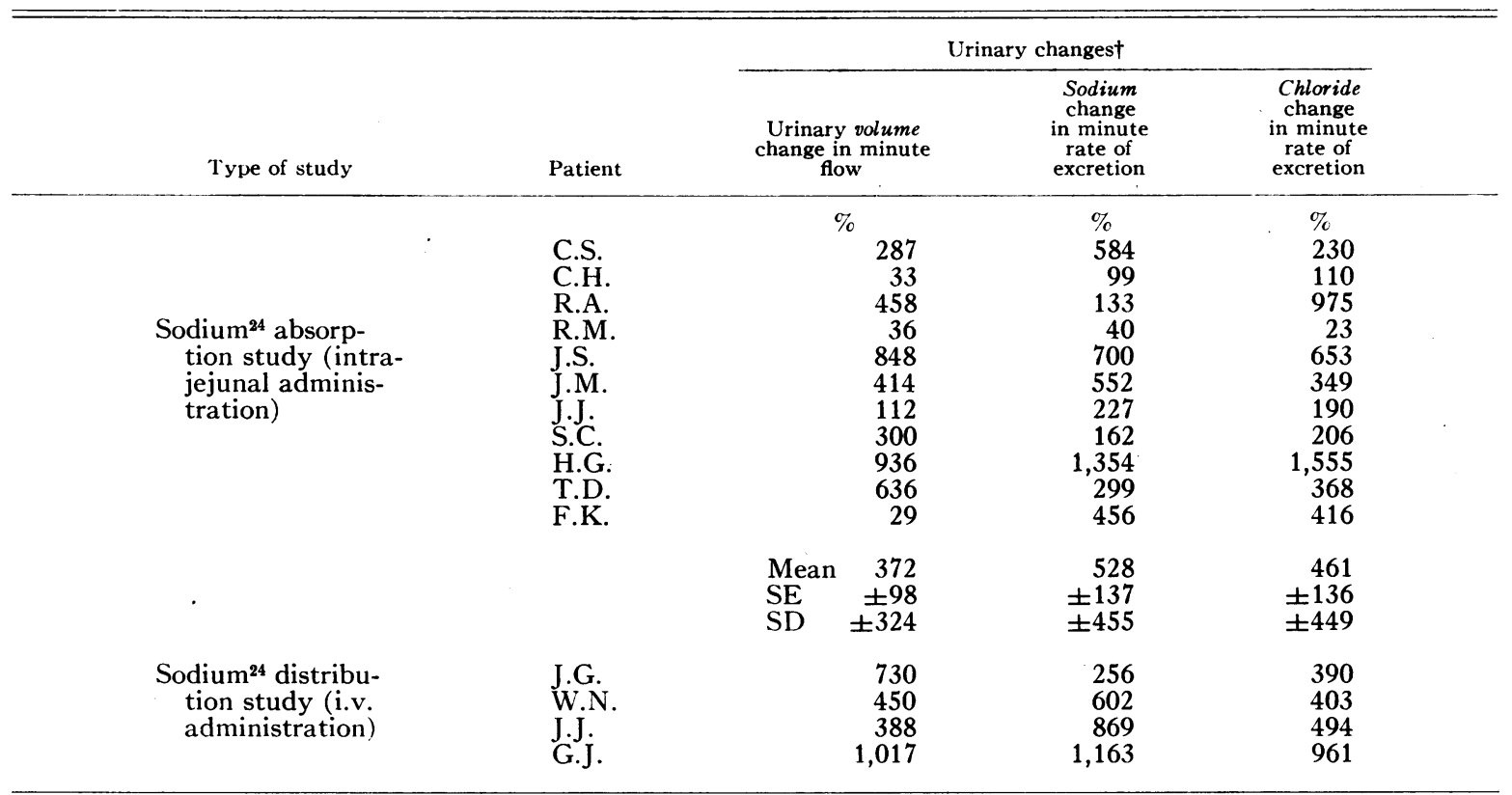

* Administered intravenously following control sodium ${ }^{24}$ study. Second study started at time of urinary changes recorded in table, 70 to 120 minutes after mercaptomerin administration.

$\dagger$ Per cent change from control levels. All values represent an increase above control levels.

tients who manifested increased motor function, absorption was reduced despite the increase in per cent duration and amplitude of type I activity. It is of considerable interest, however, that in one of these patients (A.C.) sodium ${ }^{24}$ absorption after propantheline was within the 80 percentile range for normal subjects. The other patient (J.L.), who had increased motility after propantheline, had greatly decreased absorption.

Effect of spreading sodium ${ }^{24}$ over jejunal mucosa on propantheline-induced inhibition of absorption. The mean absorption of sodium $^{24}$ fol-

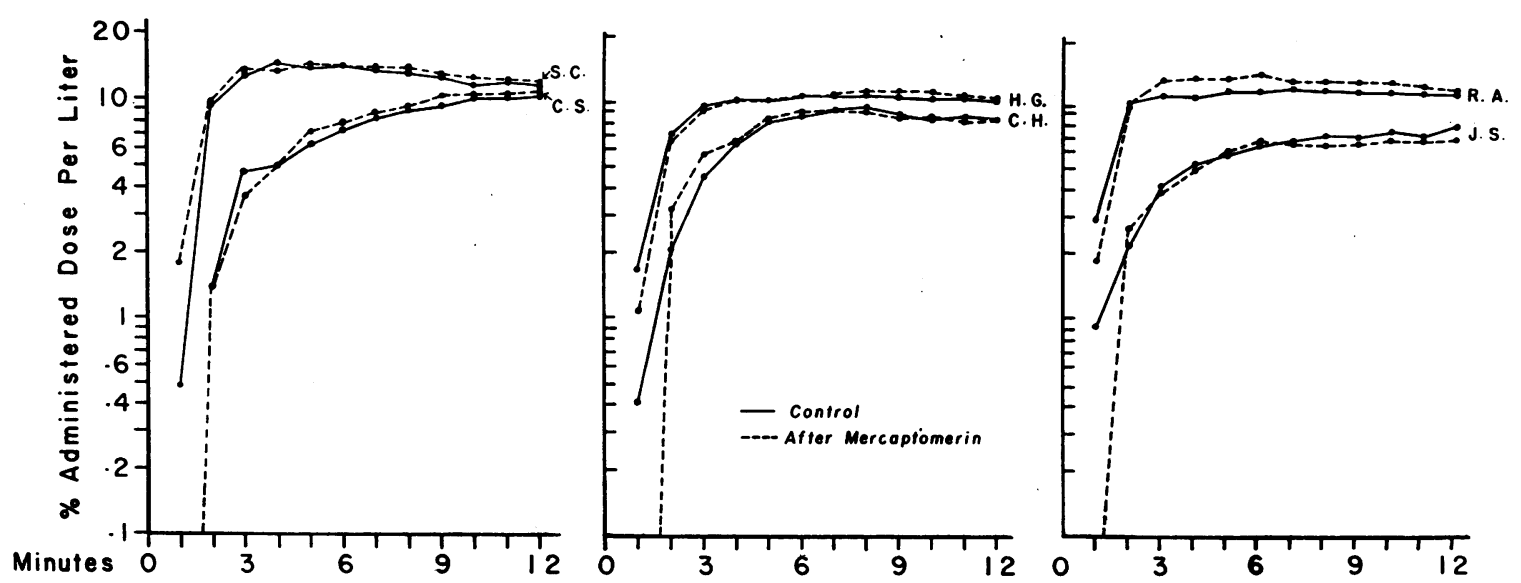

Fig. 6. Arterial concentration curves after intrajejunal administration of sodium ${ }^{24}$ in Six paTIENTS BEFORE AND AFTER MERCAPTOMERIN. These six patients were selected to demonstrate the variation in control absorption which exists between different patients, as well as to demonstrate the absence of a mercaptomerin effect on sodium transport from the intestine. 
lowing propantheline administration was not appreciably changed by mechanically spreading the sodium $^{24}$ over approximately 2.5 to 3 feet of jejunal mucosal surface. In the six patients in whom the sodium ${ }^{24}$ was artificially dispersed over the jejunum, absorption at 5 and 12 minutes was 29 and 58 per cent of the administered dose, respectively, compared with absorption of 27 and 55 per cent in the eight patients who received propantheline, but in whom no attempt was made at dispersion of the test solution.

\section{Effect of parenteral mercaptomerin adminis- tration on sodium absorption}

In seven of the 11 patients, a definite, marked increase in natriuresis followed mercaptomerin administration (Table III). In three patients (J.J., R.A. and C.H.) the effect was present but not marked, and in one patient (R.M.) little effect was noted. The mean per cent increase in urinary flow for the 11 patients as compared with control rates of flow was 372 per cent per minute, $\mathrm{SE} \pm 98$; the mean per cent increase of sodium excretion was $528, \mathrm{SE} \pm 137$; the mean per cent increase of chloride excretion was $461, \mathrm{SE} \pm 136$.

The arterial plasma concentration curve of so-

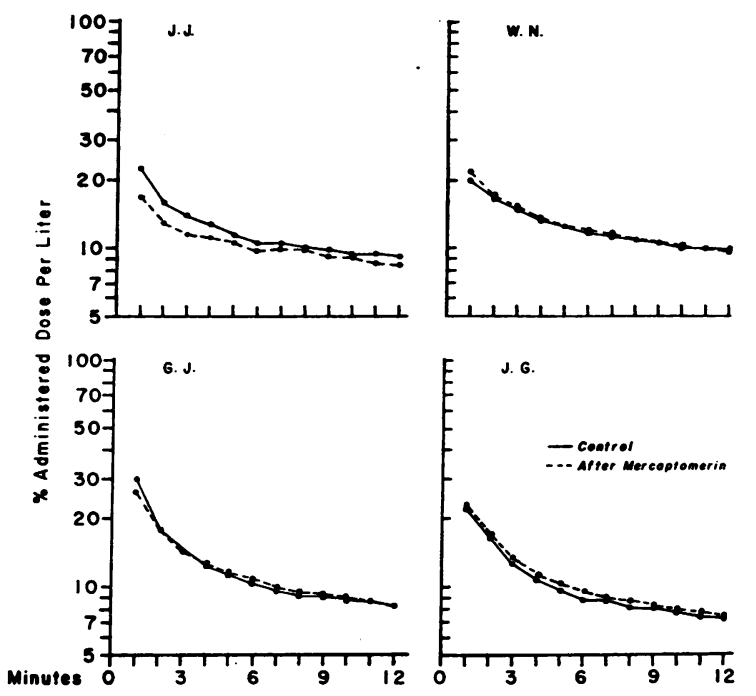

Fig. 7. Arterial disappearance curves after intraVENOUS ADMINISTRATION OF SODIUM ${ }^{24}$ BEFORE AND AFTER MERCAPTOMERIN. The closeness of the two curves suggests that the mercaptomerin does not significantly affect the distribution of the sodium ${ }^{24}$ during the first 12 minutes. dium $^{24}$ following mercaptomerin administration was in each case very similar to that of the control (Figure 6). The mean differences between the concentrations in the control test, minus those after mercaptomerin at $2,3,5$ and 8 minutes, respectively, were: $+0.01,-0.15,-0.12,+0.34$. These values do not differ significantly from 0,0 ; 0,0 nor do they differ significantly from one another by Hotelling's $t$ test or the conventional $\mathrm{F}$ test.

The difference in the control arterial appearance curves of sodium ${ }^{24}$ noted between different patients was very much greater than that noted between the control and post-mercaptomerin tests in the same patient.

The arterial disappearance curve of intravenous sodium $^{24}$ in four other patients was unaffected by the administration of mercaptomerin (Figure 7 ).

\section{DISCUSSION}

\section{Sodium absorption}

Sodium ${ }^{24}$ in an isotonic saline solution was transported rapidly from the intestinal lumen into the arterial circulation. In 22 control tests, the unidirectional transfer of 50 per cent of the test dose of isotopic sodium occurred in a mean of $4.3 \mathrm{~min}$ utes as compared with a mean of 6.1 minutes in 13 normal patients studied elsewhere $(3,4,14)$. Although it is possible that the absorption of greater than 100 per cent of administered sodium ${ }^{24}$ in seven patients represented re-excretion of sodium $^{24}$ into the intestinal lumen, it is more likely that the errors of the method largely accounted for this finding. Reproducibility of the rate at which sodium was absorbed from the intestine in nine repeat control tests was demonstrated to be quite good. On the basis of this reproducibility, the technique of using a patient as his own control was utilized in further studies. When only intraindividual differences were compared, as in the case of the evaluation of the effect of organomercurial administration on the absorption of sodium ions, sodium spaces of distribution were not required. This facilitated the study by eliminating the laborious mathematical calculations needed to integrate concentration with distribution values. It was first determined, however, that no change in the distribution of sodium resulted from mer- 
captomerin administration. When inter-individual differences in sodium absorption were analyzed, as in the study of intestinal motility and sodium absorption, it was essential to measure the rate of arterial appearance and disappearance of the test substance. The ability to accurately trace the distribution of sodium throughout the body (15) is essential to this technique, and offers a dimension in the study of absorption from the intact human small bowel which is lacking when rates of absorption of such commonly used substances as glucose, vitamin $\mathrm{A}$, triolein and oleic acid are determined (16). It should be noted, however, that the validity of this method $(8,17)$ depends in part upon how accurately the distribution of intravenous sodium ${ }^{22}$ reflects the distribution of the sodium ${ }^{24}$ absorbed from the intestine. Since sodium ${ }^{24}$ must pass through the intestinal mucosa, liver and/or lymphatics before reaching the systemic circulation, it is possible that the two isotopes are not identically distributed during the first few minutes. This question has not been completely resolved but experiments in dogs (18) in which sodium ${ }^{24}$ was injected into the portal vein suggest that the difference in route of administration may not introduce significant errors.

\section{Intestinal motility and sodium absorption}

Moderate positive correlation between type I waves, the "segmenting" waves, and transfer of sodium ions from intestinal lumen to arterial blood was observed. Particularly in patients in whom two control absorption and motility studies were performed, there was a parallel relationship between increased or decreased absorption and corresponding increase or decrease in segmental motor activity. However, the finding of normal rates of sodium transport in the presence of little intestinal motor activity of any type suggests that motility may not be as crucial a factor in the absorption of sodium from a saline medium as has been postulated $(3,4)$. It is quite possible that intestinal motor activity may be of greater importance to the efflux of sodium from the lumen when the administered sodium is mixed with a more viscous substance such as food. A greater degree of churning would be then required to achieve continuous optimal mucosal contact. The observation that a constant proportion of sodium ${ }^{24}$ remaining in the intestinal lumen enters the blood stream every minute until 90 per cent is absorbed suggests that an optimal absorbing surface is achieved within a few minutes in the normal bowel. A similar exponential rate of absorption has been noted previously for $\mathrm{D}_{2} \mathrm{O}(18)$.

Any discussion of the relationship between absorption and motility must include a consideration of the methods used to record motility. In these studies we have employed a device which detects the intraluminal pressure at one point in the jejunum. The intraluminal pressure record at one point may not be the same as that in the remainder of the small intestine, although it is reasonable to suppose that it is. The system we have used does not yield information on gradients of pressure between two adjacent areas of the bowel. Since intraluminal contents move as a result of these gradients, such information would be valuable in assessing those waves that effect propulsion of contents. Ideally intraluminal pressure at several points should be measured and propulsion of contents simultaneously recorded by a separate means. In spite of the limitations of the method used in these studies, it does represent a quantitative, reliable way of recording the motor activity of one segment.

Although the present data confirm the fact that the decrease in absorption which follows administration of an anticholinergic drug may be in part related to diminished motor activity [particularly propulsive activity (3)], a finding of similarly reduced transport of sodium ions after sodium was mechanically spread over 3 feet of jejunal surface suggests that other factors must be considered. It is known that anticholinergics alter secretion into the intestine (19). Atropine has been shown to decrease mean central venous pressure and alter cardiac output (20). It is possible, therefore, that intestinal blood flow is altered by atropine or synthetic parasympathomimetic drugs. Although evidence is lacking, another possibility is that anticholinergics may influence the metabolic activity of the intestinal mucosa which has been demonstrated to cause active sodium and chloride transport $(21,22)$. The effect of propantheline on the hepatic clearance of sodium is an additional unknown consideration which may be significant. 


\section{Effect of mercaptomerin on sodium absorption}

The present studies indicate that a parenteral organomercurial compound, mercaptomerin, does not appreciably affect the unidirectional transport of sodium ${ }^{24}$ ions during a period when a definite renal effect is manifest. This would suggest that the jejunal and ileal mucosa in man does not respond similarly to the renal tubules after a mercurial diuretic. This is in contrast to previous findings of decreased absorption of sodium $(6,7)$ and chloride ( 7 ) after mixing the saline with meralluride (Mercuhydrin). The difference in results between these experiments may be a function of the effective concentration of the mercurial at the mucosa. Blickenstaff (7) administered $2 \mathrm{ml}$ of meralluride with the $\mathrm{NaCl}$ into a jejunal ring fistula in dogs. The resultant concentration of the mercurial compound at the mucosa was probably very greatly in excess of that achieved by parenteral administration of the same dose of mercaptomerin in man. Few data exist on the concentration of mercury in the intestine after parenteral organomercurial administration, and what information does exist is principally derived from animal studies. In the rat and dog, variable amounts of radioactivity were found in the gut wall after parenteral administration of $\mathrm{Hg}^{203}$-labeled chloromerodin [Neohydrin (23)]. In these experiments, however, the intestine accounted for a very small fraction of the radioactivity found in the kidney. In one patient with advanced renal disease, autopsied 24 hours after administration of $\mathrm{Hg}^{203}$-labeled mercaptomerin, appreciable radioactivity was present in the colon (24), but the small intestine was not studied.

The probable low concentration of a mercurial agent in the small intestinal mucosa of man would raise the question as to whether the failure to inhibit sodium ${ }^{24}$ absorption in these experiments is due, not to differences in the mechanism of sodium transport between intestine and renal tubules but, simply, to the concentration of the mercurial agent in the mucosa.

The possibility exists that a parenteral mercurial might affect intestinal mucosal transport of $\mathrm{Na}^{+}$ or $\mathrm{Cl}^{-}$ions at a time other than that chosen in these experiments. It seemed reasonable, however, to use the response of the kidney as an indication of mercurial action.

\section{SUMMARY}

1. The quantitative characteristics of normal sodium absorption, i.e., unidirectional transfer of sodium ions from lumen to blood, have been studied by integrating the arterial appearance of sodium $^{24}$ after jejunal administration with the arterial disappearance of sodium ${ }^{22}$ following intravenous administration. In 22 control tests a mean of 62 per cent of the administered dose was absorbed in 5 minutes; a mean of 93 per cent was absorbed in 12 minutes. Arterial concentration curves of sodium ${ }^{24}$ during the first 8 minutes were closely correlated with calculated absorption curves during this period.

2. When calculated in terms of amount of sodium $^{24}$ remaining in the intestinal lumen, transfer of sodium ${ }^{24}$ to arterial blood proceeded at an exponential rate.

3. In nine patients, repeat control tests of intestinal absorption of sodium $^{24}$ under identical conditions indicated a high degree of reproducibility. The technique of using a patient as his own control has been useful in the present studies on the effect of motility and organomercurial administration upon the transport of sodium from the intestinal lumen to arterial blood.

4. Intestinal motility as reflected by jejunal intraluminal pressure was simultaneously recorded in 15 control tests of sodium ${ }^{24}$ absorption. There was some correlation between the amount absorbed and the amount of motor activity present. However, normal absorption occurred in several patients at a time when little motor activity was present. It is concluded that intestinal motility as here recorded probably does not play a critical role in the absorption of isotopic sodium from an isotonic saline solution in the normal small bowel.

5. The unidirectional transfer of sodium from intestinal lumen to arterial blood was significantly decreased after propantheline administration in eight patients. This reduction in absorption was not prevented in six additional patients who received propantheline and had artificial spread of the sodium ${ }^{24}$ over 3 feet of jejunal mucosal surface. These findings suggest that the inhibition of intestinal motility which occurs after an administration of an anticholinergic agent may not be primarily responsible for the decrease in absorption. 
6. The effect of an organomercurial, mercaptomerin, on the intestinal absorption of sodium ${ }^{24}$ has been studied in 11 convalescent patients. No effect on the unidirectional transport of sodium from the intestinal lumen to arterial blood was present at a time when a mercurial effect on the kidney was observed.

\section{ACKNOWLEDGMENT}

The authors wish to express their appreciation to Dr. James Bernstein and Dr. Alan Deutsch for their assistance with the motility studies, to Dr. Marcus Rothschild and Dr. Murray Oratz for their helpful advice, and to Mrs. Dorothy Bennett for secretarial assistance. For the statistical analyses we are indebted to Miss Lee Herrera of the Department of Medical Statistics of New York University.

\section{REFERENCES}

1. Groisser, V. W., and Farrar, J. T. Factors influencing the absorption of radioactive sodium $\left(\mathrm{Na}^{24}\right)$ from the jejunum (abstract). Clin. Res. 1959, 7, 33.

2. Farrar, J. T., and Groisser, V. W. The effect of organomercurials on the absorption of $\mathrm{Na}^{24}$ from the human small intestine (abstract). J. clin. Invest. 1959, 38, 1003.

3. Higgins, J. A., Code, C. F., and Orvis, A. L. The influence of motility on the rate of absorption of sodium and water from the small intestine of healthy persons. Gastroenterology 1956, 31, 708.

4. Higgins, J. A., Lee, P. R., Scholer, J. F., Reitemeier, R. J., Code, C. F., and Wollaeger, E. E. Absorption of water and sodium from the small intestine of patients with nontropical sprue. J. clin. Invest. 1957, 36, 265.

5. Newsholme, G. A., and French, J. M. Absorption of ${ }^{24} \mathrm{NaCl}$ from the small intestine in the sprue syndrome. Clin. Sci. 1954, 13, 607.

6. Visscher, Maurice B. Electrolyte and water movement across the intestinal wall. Ann. N. Y. Acad. Sci. 1953, 57, 291.

7. Blickenstaff, D. D. Effect of meralluride and of mercuric chloride on intestinal absorption of $0.9 \%$ $\mathrm{NaCl}$ solution. Amer. J. Physiol. 1954, 178, 371.

8. Scholer, J. F., and Code, C. F. Rate of absorption of water from stomach and small bowel of human beings. Gastroenterology 1954, 27, 565.

9. Snedecor, G. W. Statistical Methods Applied to Experiments in Agriculture and Biology, 5th ed. Ames, Iowa State College Press, 1956.
10. Farrar, J. T., and Bernstein, J. S. Recording of intraluminal gastrointestinal pressures by a radiotelemetering capsule. Gastroenterology 1958, 35, 603.

11. Code, C. F., Hightower, N. C., Jr., and Morlock, C. G. Motility of the alimentary canal in man; review of recent studies. Amer. J. Med. 1952, 13, 328.

12. Berry, J. W., Chappell, D. G., and Barnes, R. B. Improved method of flame photometry. Industr. engng chem. (Anal.) 1946, 18, 19.

13. Van Slyke, D. D., Hiller, A., and Plazin, J. Application of Sendroy's iodometric chloride titration to protein-containing fluids. J. biol. Chem. 1947, 167, 107.

14. Reitemeier, R. J., Code, C. F., and Orvis, A. L. Comparison of rate of absorption of labeled sodium and water from upper small intestine of healthy human beings. J. appl. Physiol. 1957, 10, 256.

15. Edelman, I. S., Olney, J. M., James, A. H., Brooks, L., and Moore, F. D. Body composition: Studies in the human being by the dilution principle. Science 1952, 115, 447.

16. Reitemeier, R. J. Newer physiology of absorption from the intestine. Ann. intern. Med. 1959, 51, 993.

17. Scholer, J. F., Orvis, A. L., Higgins, J. A., and Code, C. F. Use of dual isotopes in determination of rates of absorption in intact animals. Amer. J. Physiol. 1955, 183, 659.

18. Code, C. F. Normal rates of absorption of $\mathrm{H}_{2} \mathrm{O}, \mathrm{Na}$ and $\mathrm{K}$, in man and animals. Symp. on Absorption of Water and Electrolytes from the Gastrointestinal Tract. Chicago, Gastroenterology Research Group, October 31, 1958.

19. Goodman, L. S., and Gilman, A. The Pharmacological Basis of Therapeutics, 2nd ed. New York, Macmillan, 1955, p. 548.

20. Berry, J. N., Thompson, H. K., Jr., Miller, D. E., and McIntosh, H. D. Changes in cardiac output, stroke volume, and central venous pressure induced by atropine in man. Amer. Heart J. 1959, 58, 204.

21. Curran, P. F., and Solomon, A. K. Ion and water fluxes in the ileum of rats. J. gen. Physiol. 1957, 41, 143.

22. Gilman, A., and Koelle, E. S. Ion transport in the gut circulation. Circulation 1960, 21, 948.

23. Borghgraef, R. R. M., and Pitts, R. F. The distribution of chlormerodrin (Neohydrin ${ }^{\circledR}$ ) in tissues of the rat and dog. J. clin. Invest. 1956, 35, 31.

24. Aikawa, J. K., and Fitz, R. H. The distribution of $\mathrm{HG}^{203}$-labeled mercaptomerin in human tissues. J. clin. Invest. 1956, 35, 775. 